\title{
An iridoid, lamiide, its extraction method from Phlomis bruguieri, and evaluation of its antioxidant capacity
}

\author{
Behzad Zolfaghari, ${ }^{1}$ Azade Esparham, ${ }^{1}$ Ebrahim Sajjadi, ${ }^{2}$ Mustafa Ghanadian ${ }^{1,2}$ \\ ${ }^{1}$ Department of Pharmacognosy, Isfahan Pharmaceutical Sciences research center, school of Pharmacy and \\ Pharmaceutical Sciences, Isfahan University of Medical Sciences, Isfahan; ${ }^{2}$ Phytochemistry Research \\ Center and School of Pharmacy, Shahid Beheshti University of Medical Sciences, Tehran, Iran
}

\begin{abstract}
Phlomis bruguieri is a native plant in Iran, which deserves phytochemical study. The aim of this study was evaluation of its iridoid contents along with its antioxidant capacity. Aerial parts of the plant material were extracted with methanol and applied on repeated normal column chromatography using hexane: chloroform (70:30), chloroform: methanol (90:10), and methanol $(100 \%)$. The fraction eluted with methanol (100\%) containing polar glycosides was selected and medium pressure liquid chro-
\end{abstract}

Correspondence: Mustafa Ghanadian, Department of Pharmacognosy, School of Pharmacy, Isfahan University of Medical Sciences, Isfahan, Iran.

Tel.: +98.3117922553 .

E-mail: ghannadian@gmail.com

Key words: Phlomis bruguieri; iridoid; lamiide; antioxidant activity.

Acknowledgements: This paper is part of thesis of Azade Sparham submitted in partial fulfillment of the requirements for the degree of Pharm D. She is also grateful to the Isfahan Pharmaceutical Sciences Research Center, Pharmacy faculty, Isfahan University of Medical Sciences, Isfahan, I.R. Iran for their support.

Contributions: BZ and ES participated in Pharmacognosy experiments. AS is the pharm D student whom this project is determined for her required for her Pharm Degree. MG contributed to elucidation of lamiide and finalizing the manuscript. All authors read and confirmed final version and publication of the manuscript.

Conflict of interest: The authors declare no conflict of interest.

Funding: It has been supported by Isfahan Pharmaceutical Sciences Research Center, Isfahan University of Medical Sciences (Grant No 397547 approved in 2019).

Received for publication: 20 September 2020.

Revision received: 6 December 2020.

Accepted for publication: 6 December 2020 .

This work is licensed under a Creative Commons Attribution NonCommercial 4.0 License (CC BY-NC 4.0).

CC Copyright: the Author(s),2020

Licensee PAGEPress, Italy

Infectious Diseases and Herbal Medicine 2020; 1:109

doi:10.4081/idhm.2020.109 matography (MPLC) on a RP-18 cartridge. Fraction elute by $\mathrm{MeOH}$ : water 30:70 was loaded on HPLC on RP-18 column for final purification. Structure elucidation was done using 1D and 2D NMR, and mass spectra. Antioxidant activity including total antioxidant capacity, DPPH and FRAP methods were designated to assess the in vitro antioxidant capacities. This study indicated the presence of lamiide as iridoid compound in the aerial parts of Phlomis bruguieri for the first time in this plant $[350 \mathrm{mg} / 2 \mathrm{~kg}$; $0.0175 \%(\mathrm{w} / \mathrm{w})]$. Lamiide showed moderate antioxidant activity using TAC $\left(\mathrm{EC}_{50}: 55 \mu \mathrm{g} / \mathrm{mL}\right.$; ascorbic acid $\left.\mathrm{EC}_{50}: 7.5 \mu \mathrm{g} / \mathrm{mL}\right)$, DPPH $\left(\mathrm{EC}_{50}: 116.2 \pm 3.51 \mu \mathrm{g} / \mathrm{mL}\right.$; ascorbic acid:34.7 \pm 0.97 $\mu \mathrm{g} / \mathrm{mL}$ ), and FRAP $\left(\mathrm{EC}_{50}:>200 \mu \mathrm{g} / \mathrm{mL}\right.$; quercetin: $7.5 \pm 0.68$ $\mu \mathrm{g} / \mathrm{mL}$ ) methods.

\section{Introduction}

Phlomis species from Lamiaceae family are distributed in North Africa, throughout Europe, and Asia. ${ }^{1}$ They have been used as herbal to protect the kidney, liver, and cardiovascular system, ${ }^{2}$ for treatment of painful swellings, psoriasis, and skin eruptions, ${ }^{3}$ lesion and burns, ${ }^{4}$ stomach ache and gastrointestinal troubles, ${ }^{5}$ antidiabetic. ${ }^{6}$ Even, grilled leaves of some species have reported for culinary use. ${ }^{7}$ Essential oils, flavonoids, Iridoids, phenylethyl alcohol glycosides are their major secondary metabolites. ${ }^{1}$ In the case of Iridoids, 8-O-acetylshanzhiside methyl ester, shanzhiside methyl ester, and lamiide are more frequent which are distributed in most of the Phlomis species. ${ }^{8}$ In pharmacological properties, they are reported for reducing the oxidative stress in diabetes or by stimulating the production of enzymes implicated in glucose metabolism. ${ }^{9}$ Mohajer et al. also reported pain reliving and analgesic properties of different Phlomis species. ${ }^{10}$ Their aqueous extract in some species have been studied for the gastroprotective activity. ${ }^{11}$ In another study conducted by Ismailoglu and coworkers, phenylethyl alcohol fraction and iridoid fraction of Phlomis pungens prevented the inhibition of acetylcholine response induced by electrolysis in aortic rings. ${ }^{12}$ They showed also protective activity in free radical-induced impairment of endotheliumdependent relaxation which probably id because of free radical scavenging activity of these compounds. ${ }^{12}$ Phlomis bruguieri $(P$. bruguieri) is distributed in flora of Turkey, Iran, and Iraq. ${ }^{13}$ Previous biological studies reported its antimicrobial against Streptococcus sanguis and Staphylococcus aureus, antioxidant, and $\alpha$-amylase inhibitory activities. ${ }^{14}$ Previous phytochemical studies showed that the main constituents of its essential oil are bicyclogermacrene $(4.1 \%), \gamma$-elemene $(16.5 \%)$, germacrene D $(60.5 \%)$, and germacrene B (7.1\%). ${ }^{15}$ In another study LC mass analysis reported presence of phenylethanoid glycosides: verbascoside, leucosceptosides A, isoverbascoside, and martynoside. ${ }^{16}$ 
Another phytochemical study by the authors, leaded in isolation of one new 4'-methoxy-luteolin-7-phosphate as well as three flavones: luteolin, tricin, and apigenin ${ }^{17}$ in semi polar partition of this plant. In this study we investigated the major component in aqueous partition of Phlomis bruguieri in addition to its antioxidant activity.

\section{Materials and Methods}

NMR spectra were taken in DMSO-d6 as the solvent on a Bruker AV400 NMR spectrometer (Bruker, Germany). High resolution mass spectra were carried out on an Agilent 1100 SL series mass spectrometer. Column Chromatography (CC) was done on flash silica gel particle size 40-63 $\mu \mathrm{m}$, and Size Exclusion Chromatography (SEC) on Sephadex LH-20 (Sigma-Aldrich). HPLC was done on a waters 501 pump and YMC RP-18 column $(250 \times 20 \mathrm{~mm})$ with AcCN:H20 (10:90) at $3.0 \mathrm{~mL} / \mathrm{min}$.

\section{Plant material}

Aerial parts of $P$. bruguieri were collected from Kermanshah, Iran. It was identified according to the voucher specimen (2182) deposited in the herbarium of biology department, Faculty of Science, University of Isfahan, Isfahan, I.R. Iran.

\section{Extraction and isolation}

Dried powder of $(2.0 \mathrm{Kg})$ was extracted with methanol $(20 \mathrm{~L})$ for one week. It was filtered and concentrated (361 g) by rotary evaporator at $40{ }^{\circ} \mathrm{C}$. The extract was defatted in a separating funnel by partitioning between methanol: water and hexane. Methanolic phase was concentrated ( $80 \mathrm{~g}$ ) and applied on column chromatography (silica gel, $400 \mathrm{~g}$ ) for preliminary fractionation using hexane: chloroform (70:30), chloroform: methanol (90:10), and methanol (100\%). Fr. 2 eluted with chloroform: methanol (90:10) was analyzed and reported previously [17] and Fr.3, eluted with methanol (100\%) containing polar glycosides selected and loaded on MPLC on a RP-18 cartridge $(50 * 150 \mathrm{~mm})$ using $\mathrm{MeOH}$ : water 30:70; 40:60, and 50:50. Based on TLC, fraction elute by $\mathrm{MeOH}$ : water 30:70 was loaded on HPLC column on YMC RP-18 column $(20 * 250 \mathrm{~mm})$ using acetonitril: water (10:90) as solvent and yielded lamiide as major iridoid component (350 mg).

To check its antioxidant activity, total antioxidant capacity, DPPH and FRAP methods were designated to assess the in vitro antioxidant capacities.

\section{Evaluation of total antioxidant capacity}

The Total Antioxidant Capacity (TAC) was done using the method of Salmanian et al. and by some adaptation method to micro titer plates. ${ }^{18} 96$ well plate resistant to temperature was poured with $10 \mu \mathrm{L}$ of sample in different concentrations of 1,10 , $25,50,100$, and $200 \mu \mathrm{g} / \mathrm{mL}$ and in triplicate wells combined with $100 \mu \mathrm{L}$ of reagent solution containing $\left(\mathrm{NH}_{4}\right)_{2} \mathrm{MoO}_{4}(4 \mathrm{mM})$, $\mathrm{Na}_{3} \mathrm{PO} 4(28 \mathrm{mM})$, and $\mathrm{H}_{2} \mathrm{SO}_{4}(0.6 \mathrm{M})$. Well plate was incubated at $95^{\circ} \mathrm{C}$ for $1.5 \mathrm{hr}$. After cooling to room temperature, the absorbance was read at $695 \mathrm{~nm}$. Blank was $10 \mu \mathrm{L}$ of sample solutions solvent and $100 \mu \mathrm{L}$ of reagent. Ascorbic acid $200 \mu \mathrm{g} / \mathrm{mL}$ was used as control. The concentration of the sample which had $50 \%$ of total antioxidant capacity, $\left(\mathrm{EC}_{50}\right)$, was determined for sample and standard using Excel 2010 graph software.

TAC $(\%)=[(\mathrm{OD}$ control - OD sample $) / \mathrm{OD}$ control $] * 100$

\section{DPPH free radical scavenging activity}

It was done using the method of West et al. and by adaptation to 96 well plates. ${ }^{19}$ Ninety-six well plate resistant to temperature were poured with $250 \mu \mathrm{L}$ of sample in different concentrations of $1,10,25,50,100$, and $200 \mu \mathrm{g} / \mathrm{mL}$ and in triplicate wells; $100 \mu \mathrm{L}$ of 1,1-Diphenyl-2-picrylhydrazyl (DPPH) ethanol solution (0.3 $\mathrm{mM}$ ) was added. The reaction would be finished after $30 \mathrm{~min}$ at room temperature, and the absorbance values could be measured at $518 \mathrm{~nm}$. Radical scavenging activity (RSA) was calculated as follows:

RSA $(\%)=[(\text { OD blank - OD sample }) / O D \text { blank }]^{*} 100$

The concentration of the sample which could scavenge $50 \%$ of DPPH radical, $\left(\mathrm{EC}_{50}\right)$ was determined for sample and standard using Excel 2010 graph software.

Ferric ion reducing antioxidant power by potassium ferric cyanide

The Ferric ion Reducing Antioxidant Power (FRAP) was determined using the method described by West et al. ${ }^{19,20}$ but by some modification in final calculation. To $1 \mathrm{~mL}$ of sample, quercetin as standard in different concentrations of 1, 10, 25, 50, 100 , and $200 \mu \mathrm{g} / \mathrm{mL}$ and in triplicate, $2.5 \mathrm{~mL}$ of sodium phosphate buffer $(0.2 \mathrm{M}, \mathrm{pH}=6.6)$ and $2.5 \mathrm{~mL}$ of $1 \%$ potassium ferric cyanide: $\mathrm{K}_{3}\left[\mathrm{Fe}(\mathrm{CN})_{6}\right]$ were added. The solution was incubated at $50{ }^{\circ} \mathrm{C}$ for $20 \mathrm{~min}$. Methanol as negative control and quercetin in the same concentrations as positive control were added. Then after incubation, $2.5 \mathrm{~mL}$ of trichloroacetic acid (TCA, 10\%) was added, and the solution was centrifuged at $10000 \mathrm{~g}$ for $10 \mathrm{~min}$. Then, $2.5 \mathrm{~mL}$ of the supernatant, with $2.5 \mathrm{~mL}$ deionized water and $0.5 \mathrm{~mL} \mathrm{FeCl}_{3}$ $(1 \%)$ were added. The mixture was incubated at room temperature for $30 \mathrm{~min}$, and the absorbance OD was measured at $700 \mathrm{~nm}$. Quercetin $200 \mu \mathrm{g} / \mathrm{mL}$ was used as control.

\section{FRAP $(\%)=[(\mathrm{OD} \text { control }-\mathrm{OD} \text { sample }) / \mathrm{OD} \text { control }]^{*} 100$}

The concentration of the sample which had $50 \%$ of ferric ion reducing antioxidant power, $\left(\mathrm{EC}_{50}\right)$, was determined for sample and standard using Excel 2010 graph software.

\section{Results and Discussion}

Compound 1 was isolated in good quantities using MPLC on a RP-18 cartridge followed by prep HPLC column on YMC RP-18 column using acetonitrile: water (10:90) as solvent. It was obtained as a white, amorphous powder and its structure was determined based on $1 \mathrm{H}-\mathrm{NMR},{ }^{13} \mathrm{C}-\mathrm{NMR}$, HSQC, and HMBC experiments. In the HR-ESIMS spectra pseudomolecular ion at $\mathrm{m} / \mathrm{z} 445.1316$ was indicative to the molecular formula $\mathrm{C}_{17} \mathrm{H}_{26} \mathrm{O}_{12}+\mathrm{Na}^{+}$(Calcd: 445.1323). ${ }^{1} \mathrm{H}-\mathrm{NMR},{ }^{13} \mathrm{C}-\mathrm{NMR}$, HSQC, and $\mathrm{HMBC}$ analysis showed signals related to a beta pyranoglucoside substituent $\delta_{\mathrm{C}}$ $97.9\left[\delta_{\mathrm{H}} 4.38\left(1 \mathrm{H}, \mathrm{d}, J=7.9 \mathrm{~Hz}, \mathrm{H}-1^{\prime}\right)\right], 72.9\left[\delta_{\mathrm{H}} 2.94(1 \mathrm{H}\right.$, ddd, $\left.\left.J_{1^{\prime}, 2}=8.7, J_{2,3}=8.7, J_{2}, \mathrm{OH}=3.6 \mathrm{~Hz}, \mathrm{H}-2^{\prime}\right)\right], 75.6\left[\delta_{\mathrm{H}} 3.11-3.17\right.$ (overlap, H-3')], $70.0\left[\delta_{\mathrm{H}} 3.06\left(1 \mathrm{H}, \mathrm{ddd}, J_{3^{\prime}, 4^{\prime}}=9.1, J_{4^{\prime}, 5}=9.1, J_{4^{\prime}, \text { OH }}=5.1\right.\right.$ $\left.\mathrm{Hz},\left(\mathrm{H}-4^{\prime}\right)\right], 77.3\left[\delta_{\mathrm{H}} 3.11-3.17\left(1 \mathrm{H}\right.\right.$, overlap, H-5'), and $60.9\left[\delta_{\mathrm{H}}\right.$ 3.45-3.50 (overlap, H-6'a); 3.70 (1H, ddd, $J_{5^{\prime}, 6{ }^{\prime} b}=1.73$, $J_{6^{\prime} a, 6^{\prime} b}=11.70, J_{6^{\prime} b, O H}=5.9 \mathrm{~Hz}, \mathrm{H}-6$ 'b), as well as $\delta_{\mathrm{H}} 5.14\left(1 \mathrm{H}, \mathrm{d}, J_{2}\right.$, ${ }_{O H}=3.8,2$ ' $\left.-\mathrm{OH}\right), 5.02\left(1 \mathrm{H}, \mathrm{d}, J_{4}, O_{H}=5.4,4\right.$ '- $\left.-\mathrm{H}\right), 4.70\left(1 \mathrm{H}, \mathrm{d}, J_{3}\right.$, ${ }_{\mathrm{O} H}=3.9,3$ ' $\left.-\mathrm{OH}\right), 4.67\left(1 \mathrm{H}, \mathrm{t}, J_{6}, \mathrm{OH}^{\prime}=5.9, \mathrm{~Hz}\right.$ 6'-OH), one methoxy group $\delta_{\mathrm{C}} 50.9\left[\delta_{\mathrm{H}} 3.62(3 \mathrm{H}, \mathrm{bs})\right]$. Main core was consisted of 10 ${ }^{13} \mathrm{C}-\mathrm{NMR}$ resonances: a singlet methyl group $\delta_{\mathrm{C}} 21.3\left[\delta_{\mathrm{H}} 0.93(3 \mathrm{H}\right.$, s)], a three-substituted double bond [ $\delta_{\mathrm{C}} 114.4$ and 150.5 (each s); 
$\left.\delta_{\mathrm{H}} 7.33(1 \mathrm{H}, \mathrm{s})\right]$, conjugated with an $\alpha, \beta$ unsaturated esteric group $\left[\delta_{\mathrm{C}} 165.8\right]$, one methylene $\delta_{\mathrm{C}} 44.6\left[\delta_{\mathrm{H}} 1.98\left(1 \mathrm{H}, \mathrm{dd}, J_{6 a, 6 b}=14.5, J_{6 a}\right.\right.$, $\left.\left.{ }_{7}=4.2 \mathrm{~Hz}, \mathrm{H}-6_{\mathrm{a}}\right) ; 2.21\left(1 \mathrm{H}, \mathrm{dd}, J_{6 a, 6 b}=14.5, J_{6 b, 7}=5.3 \mathrm{~Hz}, \mathrm{H}-6_{\mathrm{b}}\right)\right]$, three SP3 methines: one attached to a hydroxyl function $\delta_{\mathrm{C}} 75.6$ $\left[\delta_{\mathrm{H}} 3.28\left(1 \mathrm{H}, \mathrm{ddd}, J_{6 a, 7}=4.2, J_{6 b, 7}=5.3, J_{7, \mathrm{OH}}=4.8 \mathrm{~Hz}\right) ; 4.98(1 \mathrm{H}, \mathrm{d}\right.$, $J_{7, \mathrm{OH}}=4.8,7-\mathrm{OH}$, , one hemiacetal $\delta_{\mathrm{C}} 93.0\left[\delta_{\mathrm{H}} 5.65\left(1 \mathrm{H}, \mathrm{d}, J_{1,9}=1.0\right.\right.$ $\mathrm{Hz}, \mathrm{H}-1)]$, and a simple one $\delta_{\mathrm{C}} 57.3\left[\delta_{\mathrm{H}} 2.55\left(1 \mathrm{H}, \mathrm{d}, J_{1,9}=1.0 \mathrm{~Hz}\right.\right.$, $\mathrm{H}-1)$ ], in addition to two oxygenated quaternary carbons $\delta_{\mathrm{C}} 66.9$ $(\mathrm{C}-5)$, and $77.0(\mathrm{C}-8)$, and two singlet hydroxyl groups $\delta_{\mathrm{H}} 4.36$ $(1 \mathrm{H}, \mathrm{s}), 4.48(1 \mathrm{H}, \mathrm{s})$ with $\mathrm{HMBC}$ correlation to $\mathrm{C}-5$, and $\mathrm{C}-8$, respectively. By the complete assignment of the structure using 2D-NMR spectra and comparison with the published data the structure was confirmed as lamiide (Figure 1) and is reported for the first time in this plant. ${ }^{21}$

\section{Total Antioxidant Capacity Assay}

In this assay phosphomolybdenum (VI) is reduced to phosphate/Mo (V) complex at acidic $\mathrm{pH}$. As shown in Figure 2, total antioxidant capacity of lamiide increased with increasing concentration (Dose concentration pattern). In concentrations of $1,10,25$, $50 \mu \mathrm{g} / \mathrm{mL}$ its activity was less than ascorbic acid ( $\mathrm{P}$ twotail $<0.001$ ) while at concentrations $100 \mu \mathrm{g} / \mathrm{mL}$ (P two-tail $=0.089$ ) and $200 \mu \mathrm{g} / \mathrm{mL}$ (P two-tail=0.868) difference was not significant. Lamiide showed $\mathrm{EC}_{50}$ value of TAC equal to $55 \mu \mathrm{g} / \mathrm{mL}$, while ascorbic acid determined to be equivalent to $7.5 \mu \mathrm{g} / \mathrm{mL}$ determined for $100 \mu \mathrm{L}$ of reagent solution in test (Figure 2).

\section{DPPH free radical scavenging activity}

DPPH method is free radical scavenging activity evaluation by proton donation or radical scavenging ability using pink stable radical DPPH $(\lambda \max =517 \mathrm{~nm})$. As shown in Figure 3 , free radical scavenging by lamiide was in a dose dependent pattern. In concentrations of $25,50,100 \mu \mathrm{g} / \mathrm{ml}$ its activity was less than ascorbic acid $(\mathrm{P}<0.001)$ while at concentrations $200 \mu \mathrm{g} / \mathrm{mL}$ difference was not significant $(\mathrm{P}>0.05)$. Lamiide $\mathrm{EC}_{50}$ value at concentration of 116.2 $\pm 3.51 \mu \mathrm{g} / \mathrm{ml}$, while ascorbic acid as positive control was $34.7 \pm$ $0.97 \mu \mathrm{g} / \mathrm{mL}$ (Figure 3).

\section{Determination of ferric ion reducing antioxidant power}

Reducing power assay method is based on this principle that compounds with FRAP activity, reduce ferric ion $\left(\mathrm{Fe}^{3+}\right)$ in the form of $\mathrm{K}_{3}\left[\mathrm{Fe}(\mathrm{CN})_{6}\right]$ to $\mathrm{Fe}^{2+}$ ion in $\mathrm{K}_{4}\left[\mathrm{Fe}(\mathrm{CN})_{6}\right]$, which then reacts with $\mathrm{FeCL}_{3}$ to form $\mathrm{Fe}_{4}\left[\mathrm{Fe}(\mathrm{CN})_{6}\right]_{3}$ with Prussian color that has an maximum absorption $(\lambda \max )$ at $700 \mathrm{~nm}$. As shown in Figure 4, ferric ion reducing activity by lamiide was dose dependent. Lamiide $\mathrm{EC}_{50}$ value was more than $200 \mu \mathrm{g} / \mathrm{mL}$, while quercetin was $7.5 \pm$ $0.68 \mu \mathrm{g} / \mathrm{ml}$ in this test. Lamiide at higher concentration of 200 $\mu \mathrm{g} / \mathrm{mL}$, showed $16.28 \pm 0.37 \%$ FRAP activity compared with quercetin with $100 \%$ activity (Figure 4).

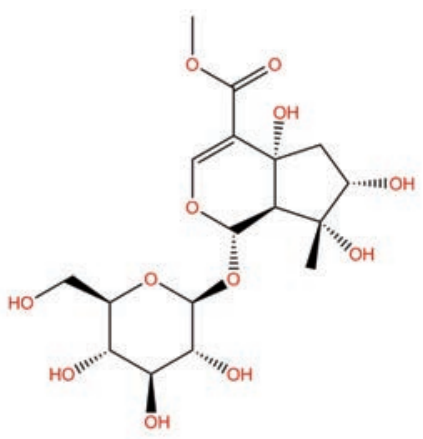

Figure 1. lamiide isolated from Phlomis bruguieri.

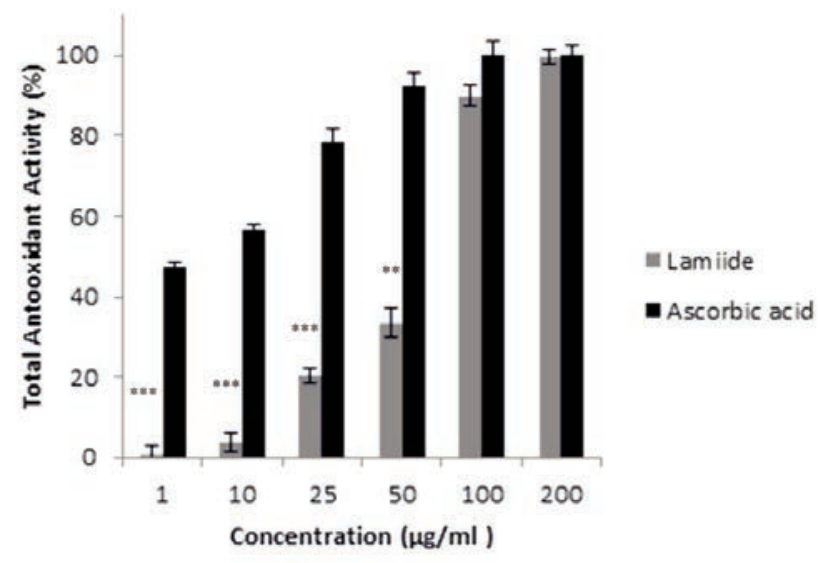

Figure 2. Total antioxidant activity of lamiide isolated from Phlomis bruguieri. Ascorbic acid was used as positive control (*** $\mathbf{p}<\mathbf{0 . 0 0 0 1},{ }^{* *} \mathbf{p}<\mathbf{0 . 0 0 1},{ }^{*} \mathbf{p}<\mathbf{0 . 0 5}$ versus control). Values are represented as mean \pm standard error $(n=3)$.

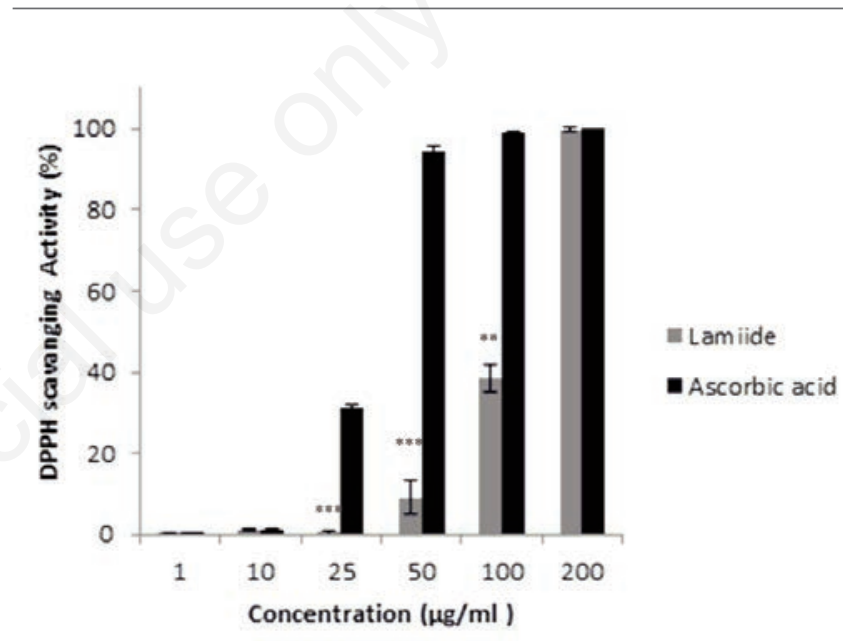

Figure 3. DPPH free radical scavenging activity of lamiide isolated from Phlomis bruguieri. Ascorbic acid was used as positive control ( ${ }^{* * *} \mathbf{p}<\mathbf{0 . 0 0 0 1},{ }^{* *} \mathbf{p}<\mathbf{0 . 0 0 1},{ }^{*} \mathbf{p}<\mathbf{0 . 0 5}$ versus control). Values are represented as mean \pm standard error $(n=3)$.

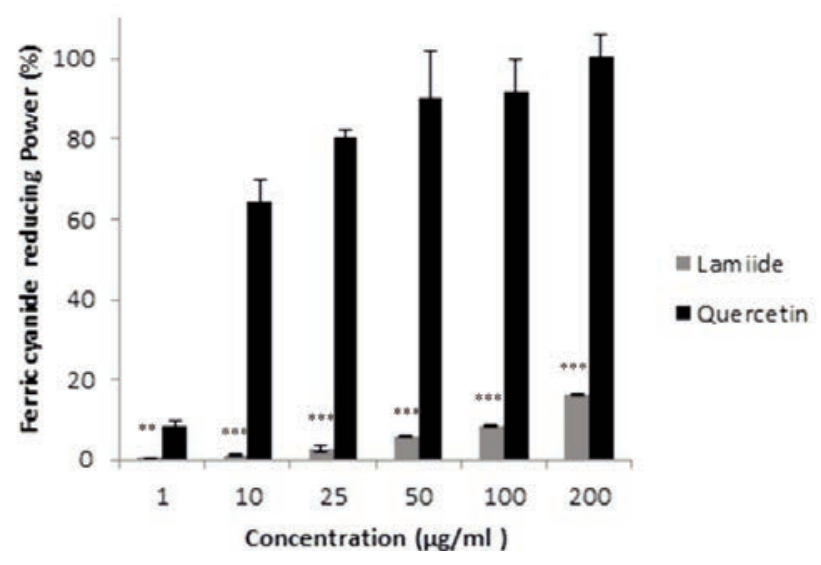

Figure 4. Ferric cyanide reducing power of lamiide isolated from Phlomis bruguieri. Quercetin was used as positive control (*** $\mathbf{p}<\mathbf{0 . 0 0 0 1},{ }^{* *} \mathbf{p}<0.001,{ }^{*} \mathbf{p}<\mathbf{0 . 0 5}$ versus control). Values are represented as mean \pm standard error $(n=3)$. 


\section{Conclusions}

This study indicated using MPLC on reverse phase C-18 followed by HPLC on prep RP C-18 columns using acetonitrile: water as solvent is a good method for purification of Lamiide iridoid. the presence of lamiide as iridoid compound in the aerial parts of Phlomis bruguieri for the first time from in this plant [350 $\left.\mathrm{mg} /{ }^{2} \mathrm{~kg} ; 0.0175 \%(\mathrm{w} / \mathrm{w})\right]$. Lamiide has been found in other Phlomis species by increasing order as following: $P$. thapsoides (9mg/2.7kg; 0.00033\%), P. persian $(4 \mathrm{mg} / 750 \mathrm{~g} ; 0.0005 \%)$, P. area (40mg/5kg; 0.0008\%), P. capitata $(6 \mathrm{mg} / 500 \mathrm{~g} ; 0.0012 \%)$, P.integriflora $(17 \mathrm{mg} / 530 \mathrm{~g} ; 0.003 \%), \quad$ P. monocephala $(15 \mathrm{mg} / 500 \mathrm{~g}$; $0.003 \%)$, P. syriaca $(14.7 \mathrm{mg} / 450 \mathrm{~g} ; 0.0032 \%)$, P.angustissima (20mg/435g; $0.0045 \%)$, P. fruticosa $(26 \mathrm{mg} / 512 \mathrm{~g} ; 0.005 \%), P$. grandiflora var. fimbrilligera $(26 \mathrm{mg} / 420 \mathrm{~g} ; 0.006 \%)$, P. physocalyx (75mg/600g; 0.0125\%), P. kotschyana (60mg/280g; 0.021\%), P. nissolii $(300 \mathrm{mg} / 1.2 \mathrm{~kg}$; 0.025\%), P. oppositiflora $(114 \mathrm{mg} / 200 \mathrm{~g}$; $0.057 \%)$, P. pungens (3g / 2.5kg;0.12\%), P. viscosa $(1794 \mathrm{mg} /$ $350 \mathrm{~g} ; 0.5 \%) .^{22-35}$ In comparison between Phlomis species, $P$. viscosa, and $P$. pungens with 0.1 to $0.5 \%(\mathrm{w} / \mathrm{w})$ lamiide content could be considered as most rich sources of lamiide. However, because of this fact that $P$. bruguieri contains only one major iridoid, it could be considered also as a source with $0.035 \%$ lamiide content because of less purification steps.

Lamiide showed moderate antioxidant activity using TAC $\left(\mathrm{EC}_{50:} 55 \mu \mathrm{g} / \mathrm{mL}\right.$; ascorbic acid EC50: $\left.7.5 \mu \mathrm{g} / \mathrm{mL}\right), \mathrm{DPPH}\left(\mathrm{EC}_{50}\right.$ : $116.2 \pm 3.51 \mu \mathrm{g} / \mathrm{mL}$; ascorbic acid:34.7 $\pm 0.97 \mu \mathrm{g} / \mathrm{mL}$ ), and FRAP $\left(\mathrm{EC}_{50}:>200 \mu \mathrm{g} / \mathrm{mL}\right.$; quercetin: $\left.7.5 \pm 0.68 \mu \mathrm{g} / \mathrm{mL}\right)$. These results were in agreement with DPPH activity of other iridoids as follows: 6-methoxy scandoside methyl ester $\left(\mathrm{EC}_{50}: 277.38 \mu \mathrm{g} / \mathrm{mL}\right),{ }^{36}$ longifolioside $\mathrm{A}\left(\mathrm{EC}_{50}: 127.0 \mu \mathrm{g} / \mathrm{mL}\right)$, longifolioside $\mathrm{B}\left(\mathrm{EC}_{50}: 19.0\right.$ $\mu \mathrm{g} / \mathrm{mL}),{ }^{37}$ Ixoside $\left(\mathrm{EC}_{50}: 42.4 \mu \mathrm{g} / \mathrm{mL}\right),{ }^{38}$ and 10 -O-caffeoyl scandoside methyl ester $\left(\mathrm{EC}_{50}: 2.56 \mu \mathrm{g} / \mathrm{mL}\right){ }^{36}$

Previously lamiide showed anti-inflammatory activity which support antioxidant activities. Its activity on rat-brain phospholipid peroxidation showed a prosperous activity with $\mathrm{IC}_{50}$ value of $0.92+/-0.01 \mathrm{mM}$ and an anti-inflammatory effect in a carrageenininduced paw edema in rat test with $\mathrm{ED}_{50}$ value of $62.3+/-7$ $\mathrm{mg} / \mathrm{kg} .{ }^{39}$

\section{References}

1. Amor IL, Boubaker J, Sgaier MB, et al. Phytochemistry and biological activities of Phlomis species. J Ethnopharmacol 2000;125:183-202.

2. Ertuğ F. Wild edible plants of the Bodrum area (Muğla, Turkey). Turk J Bot 2004;28:161-74.

3. Khanam M, Hassan MA. A critical study of the genus Leucas R. Br. (Lamiaceae) from Bangladesh. Bangladesh J Plant Taxon 2005;12:1-0.

4. Liolios C, Laouer H, Boulaacheb N, et al. Chemical composition and antimicrobial activity of the essential oil of Algerian Phlomis bovei De Noé subsp. Bovei. Molecules 2007;12:77281.

5. Digrak M, Alma MH, İlçim A, Sen S. Antibacterial and antifungal effects of various commercial plant extracts. Pharm Biol 1999;37:216-20.

6. Khafagi IK, Dewedar A. The efficiency of random versus ethno-directed research in the evaluation of Sinai medicinal plants for bioactive compounds. J Ethnopharmacol. 2000;71:365-76.
7. Naghibi F, Mosaddegh M, Mohammadi Motamed M, Ghorbani A. Labiatae family in folk medicine in Iran: from ethnobotany to pharmacology. Iran J Pharm Res 2010:63-79.

8. Kasai R, Katagiri M, Ohtani K, et al. Iridoid glycosides from Phlomis younghusbandii roots. Phytochemistry 1994;36:96770.

9. Sarkhail P, Rahmanipour S, Fadyevatan S, et al. Antidiabetic effect of Phlomis anisodonta: effects on hepatic cells lipid peroxidation and antioxidant enzymes in experimental diabetes. Pharmacol Res 2007;56:261-6.

10. Mohajer M. Antiinflammatory and analgesic effects of Phlomis lanceolata Boiss and Hohen. extracts and examination of their components. Int J Pharmacol 2005;2:50-4.

11. Amor IL, Skandrani I, Boubaker J, et al. Investigation of biological activity of polar extracts isolated from Phlomis crinita Cav ssp. mauritanica Munby. Drug Chem Toxicol 2009;32:3846.

12. Ismailoglu UB, Saracoglu I, Harput US, Sahin-Erdemli I. Effects of phenylpropanoid and iridoid glycosides on free radical-induced impairment of endothelium-dependent relaxation in rat aortic rings. J Ethnopharmacol 2002;79:193-7.

13. Rechinger KH, ed. Flora Iranica. Graz: Akademische Drucku Verlagsanstalt; 1982. pp. 292-317.

14. Delnavazi MR, Safaei M, Biuki S, et al. Coumaroyl flavone glycosides and cinammic acid derivatives from the aerial parts of Phlomis bruguieri Desf. Res J Pharmacognosy 2017;4:1722 .

15. Sarkhail P, Amin G, Surmaghi MH, Shafiee A. Composition of the volatile oils of Phlomis lanceolata Boiss. \& Hohen., Phlomis anisodonta Boiss. and Phlomis bruguieri Desf. from Iran. Flavour Fragr J 2005;20:327-9.

16. Kirmizıbekmez H, Montoro P, Piacente S, et al. Identification by HPLC-PAD-MS and quantification by HPLC-PAD of phenylethanoid glycosides of five Phlomis species. Phytochem Anal 2005; 16:1-6

17. Sajjadi SE, Delazari Z, Aghaei M, Ghannadian M. Flavone constituents of Phlomis bruguieri Desf. with cytotoxic activity against MCF-7 breast cancer cells. Res Pharm Sci 2018;13:422.

18. Salmanian S, Sadeghi MA, Alami M, Ghorbani M. Phenolic content, antiradical, antioxidant, and antibacterial properties of hawthorn (Crataegus elbursensis) seed and pulp extract. J Agr Sci Tech-Iran 2014;16:343-5.

19. West BJ, Deng S, Jensen CJ, et al. Antioxidant, toxicity, and iridoid tests of processed Cornelian cherry fruits. Int J Food Sci Tech 2012;47:1392-7.

20. Saloufou KI, Boyode P, Simalou O, et al. Chemical composition and antioxidant activities of different parts of Ficus sur. J Herbmed Pharmacol. 2018;7:185-92.

21. Sarkhail P, Monsef-Esfehani HR, Amin G, et al. Phytochemical study of Phlomis olivieri Benth. and Phlomis persica Boiss. Daru 2006;14:115-21.

22. Sobeh M, Mamadalieva NZ, Mohamed T, et al. Chemical profiling of Phlomis thapsoides (Lamiaceae) and in vitro testing of its biological activities. Med Chem Res 2016;25:2304-15.

23. Kamel MS, Mohamed KM, Hassanean HA, et al. Iridoid and megastigmane glycosides from Phlomis aurea. Phytochemistry 2000;55:353-7.

24. Kırmızıbekmez H, Piacente S, Pizza C, Dönmez AA, Çaliș İ. Iridoid and phenylethanoid glycosides from Phlomis nissolii and P. capitata. Z. Naturforsch. B. 2004;59:609-13.

25. Saracoğlu İ, Varel M, Çaliş İ, Dönmez AA. Neolignan, flavonoid, phenylethanoid and iridoid glycosides from 
Phlomis integrifolia. Turk J Chem 2003;27:739-48.

26. Yalcin FN, Ersoez T, Akbay P, et al. Iridoid and Phenylpropanoid Glycosides from Phlomis samia, P. monocephala and P. carica. Turk J Chem 2003;27:295-306.

27. Harput ÜŞ, Çaliş İ, Saracoğlu İ, Dönmez AA, Nagatsu A. Secondary metabolites from Phlomis syriaca and their antioxidant activities. Turk J Chem 2006;30:383-90.

28. Yalcin FN, Ersöz T, Bedir E, et al. Phlinoside F, a new phenylethanoid glycoside from Phlomis angustissima. Turk J Chem 2005;29:417-23.

29. Ersöz T, Saracoğlu İ, Harput ÜŞ, et al. Iridoid and phenylpropanoid glycosides from Phlomis grandiflora var. fimbrilligera and Phlomis fruticosa. Turk J Chem 2002;26:171-7.

30. Ersöz T, Alipieva KI, Yalçın FN, et al. Physocalycoside, a new phenylethanoid glycoside from Phlomis physocalyx Hub.Mor. Z Naturforsch C 2003;58:471-6.

31. Harput ÜŞ, Saracoğlu İ, Çaliş İ, et al. Secondary metabolites from Phlomis kotschyana. Turk J Chem 2004;28:767-74.

32. Kirmizibekmez H, Piacente S, Pizza C, et al. Iridoid and phenylethanoid glycosides from Phlomis nissolii and P. capitata. Z Naturforsch B 2004;59:609-13.

33. Çaliş İ, Bedİr E, Kirmizibekmez H, et al. Secondary metabo- lites from Phlomis oppositiflora. Nat Prod Res 2005;19:493501.

34. Saracoglu I, Suleymanov T, Shukurova A, Dogan Z. Phytochemical studies on Phlomis pungens Willd. from Azerbaijan. Planta Medica 2016;82:P285.

35. Çaliş İ, Kirmizibekmez H, Beutler JA, et al. Secondary metabolites of Phlomis viscosa and their biological activities. Turk J Chem 2005;29:71-82.

36. Lakshmana Raju B, Lin SJ, Hou WC, et al. Antioxidant iridoid glucosides from Wendlandia formosana. Nat Prod Res 2004;18:357-64.

37. Jensen SR, Gotfredsen CH, Harput US, Saracoglu I. Chlorinated iridoid glucosides from Veronica longifolia and their antioxidant activity. J Nat Prod 2010;73:1593-6.

38. Abdel-Mageed WM, Backheet EY, Khalifa AA, et al. Antiparasitic antioxidant phenylpropanoids and iridoid glycosides from Tecoma mollis. Fitoterapia 2012;83:500-7.

39. Delaporte RH, Sánchez GM, Cuellar AC, et al. Anti-inflammatory activity and lipid peroxidation inhibition of iridoid lamiide isolated from Bouchea fluminensis (Vell.) Mold.(Verbenaceae). J Ethnopharmaco 2002;82:127-30. 